\title{
Flexor pollicis longus tenosynovitis caused by Mycobacterium marinum infection
}

\author{
Karthikeyan P lyengar, Hosam E Matar, Ajegbomogum 0 Jayeola, William Y Loh
}

Department of Trauma \& Orthopaedics, Southport \& Ormskirk University Hospital NHS Trust, Southport, Merseyside, UK

\section{Correspondence to} Hosam E Matar hematar@doctors.org.uk

Accepted 6 June 2014
CrossMark

To cite: lyengar $K P$, Matar $\mathrm{HE}$, Jayeola $\mathrm{AO}$, et al. BMJ Case Rep Published online: [please include Day Month Year] doi:10.1136/ bcr-2014-205443

\section{DESCRIPTION}

Among infections of the hand, Mycobacterium marinum accounts for 0.04-0.27/100 000 cases; most are caused by superficial abrasions from water and other environmental sources. ${ }^{1} M$. marinum has an extensive habitat and lives in a warm aquatic environment, optimally cultured at a temperature of $25-35^{\circ} \mathrm{C}$. There are no pathognomonic features of $M$. marinum infections, with diverse presenting symptoms. These infections are categorised into three types: self-limiting verrucal lesions; subcutaneous granulomas; and deep infections involving the tenosynovium, bursa, bones or joints causing tenosynovitis, septic arthritis or osteomyelitis. ${ }^{2}$ Delay in making diagnosis is common due to a long inoculation period ranging from few days to few months. ${ }^{1-3}$ Initial clinical and radiological findings are often non-specific; diagnosis is confirmed by positive microbiological cultures. Treatment is by antimicrobial and surgical debridement and synovectomy of deep infections followed by an extensive rehabilitation programme to regain hand function. $^{1-3}$

We present an interesting case of flexor pollicis longus (FPL) tenosynovitis caused by $M$. marinum in a normally fit and well 38-year-old right handed woman. She sustained a superficial abrasion to her right thumb while filleting salmon at home. This turned into a painful swelling which was mistaken for cellulitis, resisting broad-spectrum antibiotics (oral co-amoxiclav in primary care settings; intravenous piperacillin/tazobactam and metronidazole in hospital care). Plain radiographs (figure 1) demonstrated soft tissue swellings; however, MRI confirmed FPL tenosynovitis (figure 2 ). The patient proceeded with surgical debridement and extended cultures of tissue specimens confirmed M. marinum infection sensitive to azithromycin, clarithromycin, gentamicin and tobramycin. She received a 6-month course of oral clarithromycin $500 \mathrm{mg}$ twice daily and clofazimine $50 \mathrm{mg}$ once daily. A targeted hand therapy programme led to eventual successful functional recovery.

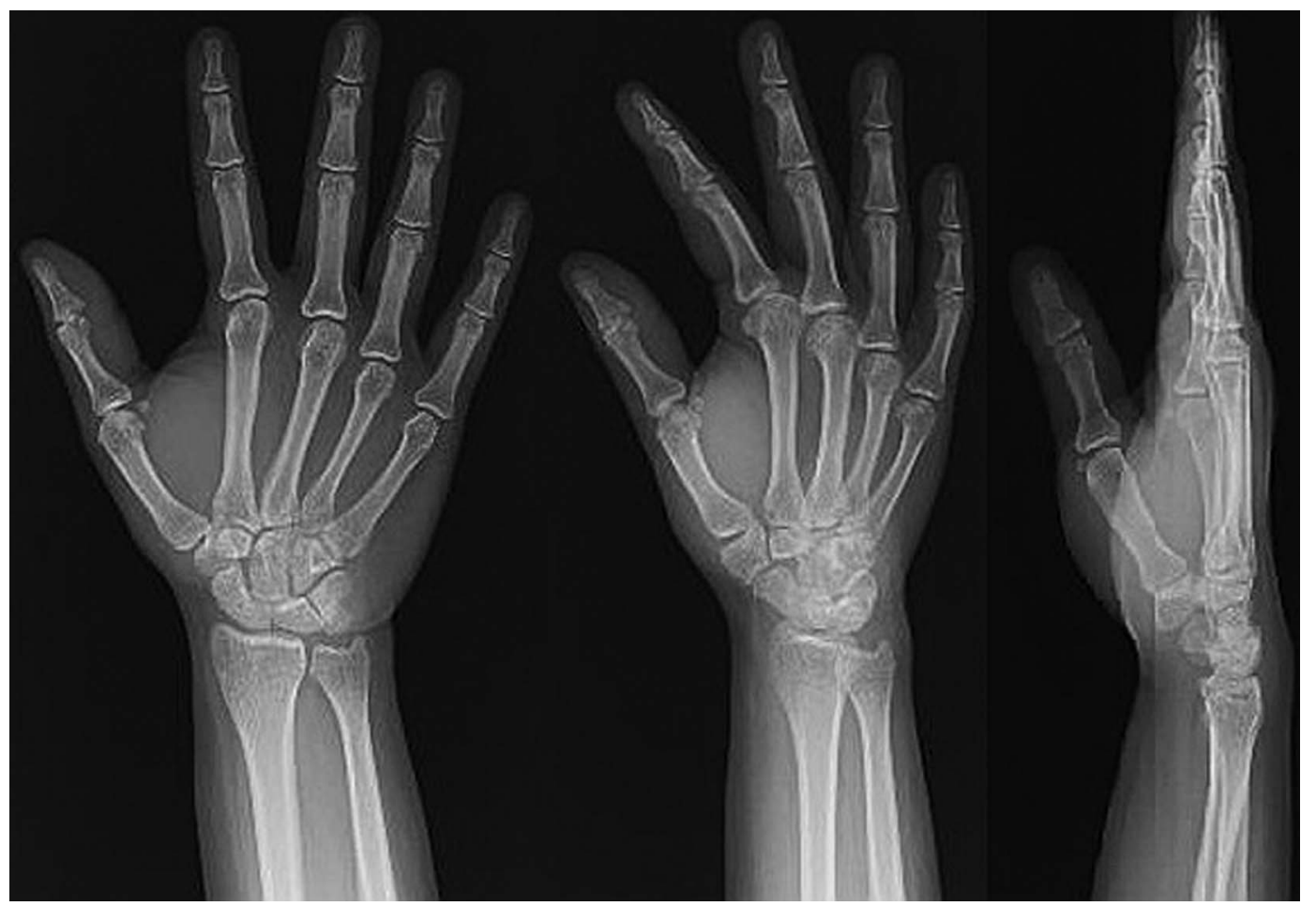

Figure 1 Anteroposterior, oblique and lateral plain radiographs of right hand/wrist demonstrating a soft tissue swelling in the hand with no bony abnormalities. 


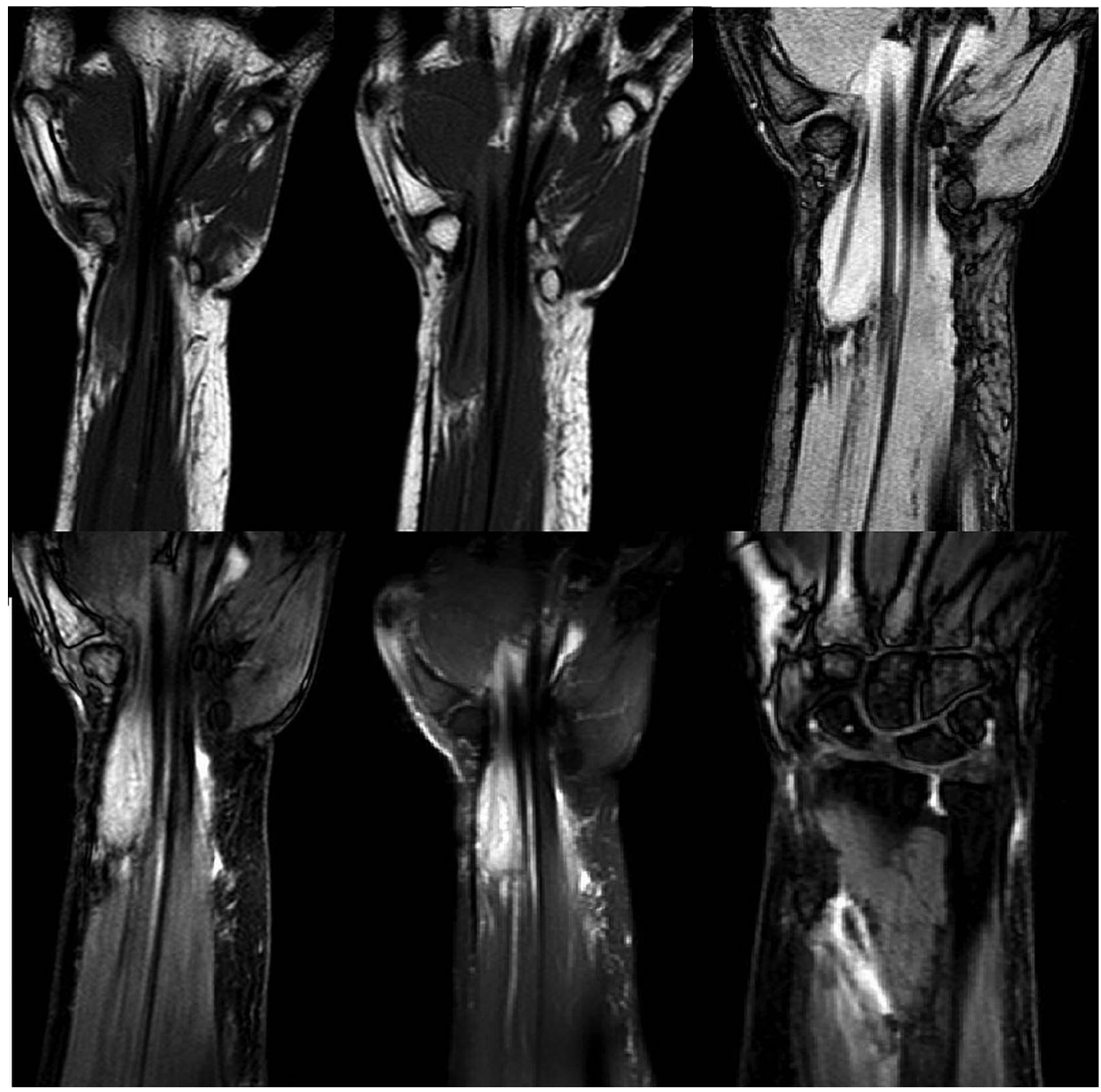

Figure 2 Coronal MRI demonstrating exuberant tenosynovitis of flexor pollicis longus with fluid collections on T1/T2 sequences with postcontrast enhancement of the thickened bursa/synovial sheath.

\section{Learning points}

- Misdiagnosis and delayed treatment of Mycobacterium marinum infection is common.

- Clinicians should have a high index of suspicion of these indolent infections; particularly in those patients with a history of trauma with exposure to marine life.

- Surgical debridement may be needed to treat these deep infections and obtaining histological and microbiological diagnosis is essential for successful treatment with appropriate antibiotics.
Competing interests None.

Patient consent Obtained.

Provenance and peer review Not commissioned; externally peer reviewed.

\section{REFERENCES}

1 Pang HN, Lee JY, Puhaindran ME, et al. Mycobacterium marinum as a cause of chronic granulomatous tenosynovitis in the hand. J Infect 2007;54:584-8.

2 Hurst LC, Amadio PC, Badalamente MA, et al. Mycobacterium marinum infections of the hand. J Hand Surg 1987;12:428-35.

3 Aubry A, Chosidow 0, Caumes E, et al. Sixty-three cases of Mycobacterium marinum infection: clinical features, treatment, and antibiotic susceptibility of causative isolates. Arch Intern Med 2002;162:1746-52. 
Copyright 2014 BMJ Publishing Group. All rights reserved. For permission to reuse any of this content visit http://group.bmj.com/group/rights-licensing/permissions.

BMJ Case Report Fellows may re-use this article for personal use and teaching without any further permission.

Become a Fellow of BMJ Case Reports today and you can:

- Submit as many cases as you like

- Enjoy fast sympathetic peer review and rapid publication of accepted articles

- Access all the published articles

- Re-use any of the published material for personal use and teaching without further permission

For information on Institutional Fellowships contact consortiasales@bmjgroup.com

Visit casereports.bmj.com for more articles like this and to become a Fellow 